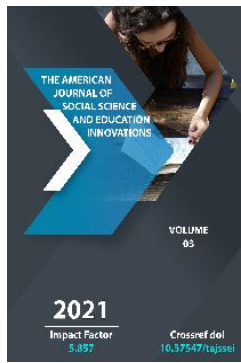

\title{
Pedagogical Properties Of "Technological Education"
}

Sobir Xudoyberdiyevich Qaxorov

Lecturer, Bukhara State University, Uzbekistan

Journal Website:

http://theamericanjour

nals.com/index.php/taj

ssei

Copyright: Original content from this work may be used under the terms of the creative commons attributes 4.0 licence.

\section{ABSTRACT}

The article presents some questions of pedagogical aspects of technological learning, considers the tasks to be solved in teaching the subject when preparing students for the system of higher pedagogical education at its various levels, taking into account their professional training.

\section{KEYWORDS}

Education, humanitarization of education, goal of professional education, principles of professional education, technologies of education.

\section{INTRODUCTION}

Educational programs for the preparation of bachelors and masters of technological education are built on the basis of an ergonomic approach to human labor activity and the ideas of humanization. 
They presuppose the formation of a wide system of knowledge among students about modern technologies of labor activity, created in the interests of a person. The programs are focused on training specialists in the field of education, service, production, entrepreneurship and are aimed at effective practical activities of the graduate.

\section{MATERIALS AND METHODS}

The educational process at the faculty is based on the principles of fundamental education, the formation of broad-profile specialists in accordance with social needs. The implementation of these principles is ensured by an in-depth study of the cycle of humanitarian and general technical disciplines, pedagogical design, artistic design, as well as the focus of the educational process on the development of research methods.

"Technological education" involves three levels (pre-university, university and postgraduate), each of which has its own goal and specific tasks.

The first stage is pre-university training, then basic general professional training (general higher education), which is the initial stage of training a bachelor's degree. The second stage is built on it - profile training, at which the bachelor's degree (basic higher education) is completed. Then specialized master training is carried out (complete higher pedagogical education.

The basis for identifying the presented structure of training a specialist in technological education was the staging of continuous vocational education, set by a multilevel training model
The main goal of the pre-university level is to prepare the opportunity for students to enter the system of higher pedagogical education at its various levels, taking into account their professional training

The basis for identifying the presented structure of training a specialist in technological education was the staging of continuous vocational education, set by a multilevel training model.

The main goal of the pre-university level is to prepare the opportunity for students to enter the system of higher pedagogical education at its various levels, taking into account their professional training.

Tasks to be solved:

- Strengthening of general professional training;

- The optimal combination of disciplines at an early stage when students choose their educational route (training profile) with the needs of the educational market;

- Providing multidisciplinary training, taking into account the qualifications of teaching staff, material base and focus of students' interests;

- A clear definition of professional status when a student leaves the system at 3, 4 and 5 courses;

- Creation of optimal conditions for the transition of students studying in the direction of "Technological education" from one pedagogical university to another. 
Strengthening the block of general professional training in the new educational standard at the expense of basic psychological and pedagogical, methodological and technological disciplines made it possible to expand the range of areas of specialized training: from those introduced (technology of construction materials; technology of processing fabrics and food products) to those in demand in modern market relations (technology of vocational training; technical and graphic design; technology of design and modeling of clothing; automotive and service car maintenance; design of household and industrial products; entrepreneurship in the field of small manufacturing business, etc.).

A bachelor of technology education is a specialist of a special kind, capable of integrating into new market relations and forming students' readiness for social and professional integration. A specialist in this field should contribute to the development of self-awareness and professional selfdetermination of trainees, for which he needs to master fundamental general scientific knowledge and skills in the field of modern technologies (production, research, social, psychological, pedagogical, informational) and entrepreneurial activities.

The Master of Technology Education program is aimed at developing students' skills to design and model the educational process in accordance with educational standards; organize experimental and innovative work in teaching staff; to carry out intraregional, interregional cooperation in the field of technology education; to build the marketing policy of an educational institution in the conditions of the functioning of the educational services market.
The main theoretical approach is the idea of training a master as an expert teacher, capable of self-identification, creative analysis and solving the problems of technological education development. The main goal of the postgraduate level is the training and retraining of specialists in the field of "Technological education" through postgraduate studies, mastering a new profile or specialization through additional educational programs.

Another important basis for structuring training can be its content. From this point of view, the structure of training a specialist in technology education should include several components. The general cultural component should contribute to the expansion of the general outlook of the specialist, as well as contribute to the formation of a general scientific worldview. The psychological and pedagogical component is a must in the system of professional pedagogical education.

In addition, it is especially significant today when training a specialist in technology education for a diversifying education system (specialized school, additional education system, etc.). The subject component provides the necessary level of professional qualifications of a specialist in his subject area.

All these components can be combined into a group of educational components of training. There is another important content component, which should ensure the readiness of a specialist to make scientifically based changes in the existing system of technological education, as well as build new models for the implementation of technological education. This is a research component, which at the first stages of 
training can be implemented as an educational and research one.

The problem of improving professionalization in the modern educational space leads to the advancement of two more grounds for structuring the training of a specialist in technological education: in character and in organization. On the first basis, the theoretical and practical components can be distinguished.

The theoretical component in the structure of training is designed to provide a fundamental education of a specialist, which will make him more mobile and make it possible to implement in practice the profile inherent in it.

The practical component is focused on the development of technological culture, both of the specialist himself, and the readiness of its transmission to students in his future professional pedagogical activity.

The content of training in the direction of "Technological education" is built within the framework of the proposed structure. In connection, we can talk about basic, specialized and specialized content.

The basic content provides general vocational training. It is fundamental and has a methodological focus. This is ensured, on the one hand, through the introduction of various disciplines and courses representing the humanities and natural sciences, focused on expanding the horizons of students and raising their general cultural level.

On the other hand, the basic content includes disciplines and courses reflecting the fundamental foundations of the subject area of technology and professional activity:
- "Applied Mechanics", "Machine Science", "Modern Basics of Production", etc. The first group includes "Theoretical Foundations of Technological Education", "Research Foundations in Technology Education". To the second group - "Psychology", "Pedagogy", "Technologies and methods of teaching technology."

The basic content is implemented at two levels of bachelor's degree, moreover, mainly in the first two years of training. The content of a bachelor's education should be focused on training in a wide range of science in the field of modern natural science, engineering, technology, pedagogy and psychology and be focused on studying and analyzing, first of all, the processes taking place in modern technological education.

Therefore, on the one hand, fundamental knowledge is needed to achieve good technical, technological and pedagogical training. On the other hand, to ensure the assimilation of scientific knowledge about technological culture as a form of human culture. In this regard, personnel training should be conducted not only with a focus on the profession, but also on the solution of relevant scientific problems. The content of profile training sets the necessary foundation for professional activity in the area that is determined by the relevant profile.

For example, if the training profile is the technology of processing structural materials, then the content of the specialized training should include the content that determines the organization of modern production, modern industrial technologies and the possibility of their use in production or in the process of teaching students in relevant 
educational institutions (school, lyceum, college ).

And so, an important place in the system of training a specialist in the direction of "Technological education" is occupied by independent work associated with the formation of technological skills, including taking into account the chosen profile of training.

\section{CONCLUSION}

The content of this independent work is the practical activity of mastering both objective actions that are part of various technological activities and methodological actions associated with teaching others to carry out this activity. It, as well as the process of enrichment with theoretical knowledge, is organized through a system of specially designed, gradually becoming more complex tasks, first in individual disciplines, and then tasks that have an integrated interdisciplinary nature.

\section{REFERENCES}

1. Bondarevskaya E.V., Kulnevich S. V. Pedago-gika: lichnost $v$ gumanisticheskih teoriyah i sistemah vospitaniya. Rostov n/D.: TTs «Uchitel», 1999.

2. Boryitko N.M. Prostranstvo vospitaniya: obraz byitiya : monogr. / nauch. red. N.K. Sergeev. Volgograd : Peremena, 2000.

3. Serikov V.V. Obrazovanie i lichnost. Teoriya i praktika proektirovaniya pedagogicheskih sistem. M. : Logos, 1999.
4. Sayfullayeva Dilafruz Axmadovna, Inamov Dilmirza Dedamirzayevich, Savriyeva Iqbol Bahodirova, Qaxorov Sobir Xudoyberdiyevich. LEVELS OF ACTIVATION THE ACTIVITIES OF STUDENTS. EPRA International Journal of Environmental Economics, Commerce and Educational Management Journal DOI: 10.36713/epra0414 |ISI I.F Value: 0.815 |SJIF Impact Factor (2020): 7.572 ISSN: 2348 - 814X Volume: 7| Issue: $4 \mid$ November 2020.

5. Toirov Zuvur, Juraev Husniddin Oltinboevich, Toshev Yunius Norovich \& Kahharov Sobir Khudoyberdievich, USING ALTERNATIVE ENERGY SOURCES DEVICES AS A TEACHING TOOLS, European Journal of Research and Reflection in Educational Sciences Vol. 8 No. 5, 2020. ISSN 2056-5852.

6. Sayfullaeva D.A., Kakhkhorov Sobir Kh., Bahronova Sh.I. INCREASING THE PROFESSIONAL CREATIVITY OF STUDENTS IN TEACHING SPECIALTIES / Сайфуллаева Д.А., Каххоров С.Х., Бахронова Ш.И. ПОВЫШЕНИЕ ПРОФЕССИОНАЛЬНОГО

ТВОРЧЕСТВА СТУДЕНТОВ В ПРЕПОДАВАНИИ

СПЕЦИАЛЬНОСТЕЙ, С. 33-36, Проблемы современной науки $и$ образования 2020. № 12 (157). Часть 2 Российский импакт-фактор: 1,72. ISSN 2413-4635 (Online) PROBLEMS OF MODERN SCIENCE AND EDUCATION 2020. № 12 (157). Part 2.

7. Safoyeva Sadokat Nasilloyevna. SYNONYMY AND ITS FEATURES, 4th Global Congress on Contemporary Sciences \& Advancements 30th April, 2021 Hosted online from Rome, Italy 
econferecegloble.com. P. 120-121, https://papers.econferenceglobe.com/ index.php/ecg/article/view/400/397.

8. Kayumova Nigora Muxtorovna, Shukurova Nigora Shavkatovna, Safoeva Sadokat Nasilloevna. The Role of the Ethnographic Vocabulary in the English and Uzbek Languages, International Journal of Innovative Technology and Exploring Engineering (IJITEE) ISSN; 2278-3075, Volume-8, Issue-9S3, July 2019, P. 1551-1554.

9. Набиева Зарина Набиевна, АСТРИД ЛИНДГРЕН АСАРЛАРИДА КИЧКИНТОЙЛАР РУХИЯТИНИНГ БАДИИЙ ИФОДАСИДА ОБРАЗЛИЛИК. INNOVATION IN THE MODERN EDUCATION SYSTEM: a collection scientific works of the International scientific conference (25th May, 2021) - Washington, USA: "CESS", 2021. Part 6 - p.

10. Набиева Зарина, КИЧкИНТОЙЛАР РУХИЯТИНИНГ БАДИИЙ ИФОДАСИДА ОБРАЗЛИЛИК. ПЕДАГОГИКА ВА ПСИХОЛОГИЯДА ИННОВАЦИЯЛАР ИННОВАЦИИ В ПЕДАГОГИКЕ И ПСИХОЛОГИИ INNOVATIONS IN PEDAGOGY AND PSYCHOLOGY №3 (2021) DOI http://dx.doi.org/10.26739/2181-95132021-3, Б. 62-67.

11. NabiyevaZ.N. The similarities and differences of proverbs with other genres

1. International journal of Psychosocial Rehabilitation, vol.24, Issue 06,2020 ISSN;1475-7192 mart

12. Nabiyeva Zarina Nabiyevna "Image In The Artistic Expression Of The Spirit of Children" INTERNATIONAL JOURNAL ON ORANGE TECHNOLOGIES www.journalsresearchparks.org/index .php/IJOT e- ISSN: 2615-8140|p-ISSN: 2615-7071 Volume: 03 Issue: 03 | March 2021

13. NabiyevaZarinaNabiyevna** "STUDY OF FRENCH GASTRONOMIC CULTURE AND THE PROBLEMOF RECIPE TEXT"ACADEMICIA: An International Multidisciplinary Research Journal https://saarj.com

ISSN: 2249-7137 Vol. 10, Issue 11, November 2020 Impact Factor: SJIF $2020=7.13$. DOI: $10.5958 / 2249$ 7137.2020.01631.6

14. Атоева М.Ф. Периодичность обучения физике. Аспирант и соискатель.

Москва, 2010. - №6. - С. 41-43.

15. M.F. Atoyeva. Interdisciplinary relations in physics course at specialized secondary education. The Way of Science. - Volgograd, 2016. №9 (31). - P.22-24.

16. M.F. Atoyeva. The significance of periodicity at teaching physics. The Way of Science. - Volgograd, 2016. № 10 (32). - P.62-64.

17. Атоева М.Ф. Эффективность обучения электродинамике на основе технологии периодичности. The Way of Science. - Volgograd, 2016. - № 10 (32). - P.65-66.

18. M.F. Atoyeva. Use of Periodicity in Teaching Physics. Eastern European Scientific Journal. - DüsseldorfGermany, 2017. № 4. -P. 35-39.

19. M.F. Atoyeva. Didactic foundations of inter-media relations in the training of university students. International Scientific Journal. Theoretical \& Applied Science. p-ISSN: 2308-4944 (print) e-ISSN: 2409-0085 (online). 
Year: 2020 Issue: 06 Volume: 86, P. 124.

20. M.F. Atoyeva, R. Safarova. Pedagogical integration as a means of forming professionally important qualities among students of a medical university. Academicia. ISSN: 2249-7137 Vol. 10, Issue 8, August 2020. Impact Factor: SJIF $2020=7.13$ ACADEMICIA: An International Multidisciplinary Research Journal https://saarj.comэ.

21. M.F. Atoyeva. Pedagogical Tests As An Element Of Types of Pedagogical Technologies. The American Journal of Applied Sciences, 2(09), (TAJAS) SJIF5.276 DOI-10.37547/tajas Volume 2 Issue 9, 19.09.2020. ISSN 2689-09. 92 The USA Journals, USA www.usajournalshub.com/index.php/t ajas 164-169. Имп.5.2.

22. Farkhodovna, A. M. (2020). The problems of preparing students for the use of school physical experiment in the context of specialized education at secondary schools. European Journal of Research and Reflection in Educational Sciences, 8 (9), 164-167.

23. Saidov S.O., Fayzieva Kh. A., Yuldosheva N. B. Atoyeva M.F. The Elements of Organization of The Educational Process On The Basis of New Pedagogical Technologies. The American Journal of Applied Sciences, 2(09), (TAJAS) SJIF-5.276 DOI10.37547/tajas Volume 2 Issue 9, 19.09.2020. ISSN 2689-09.92 The USA Journals, USA www.usajournalshub.com/index.php/t ajas 164-169. Имп.5.2.

24. Atoeva Mehriniso Farhodovna, Arabov Jasur Olimboevich, Kobilov Bakhtiyor Badriddinovich. (2020). Innovative
Pedogogical Technologies For Training The Course Of Physics. The American Journal of Interdisciplinary Innovations and Research, 2(12), 82-91.

25. Kakhkharov S.K., Juraev H.O. Alternative energy sources. Textbook. - Tashkent: NisoPoligraph, 2016. - 214 p.

26. Juraev H.O. Training Materials for Alternative Energy Sources in Education//Eastern European Scientific Journal. -Düsseldorf, 2017. № 1. -p. 127-131.

27. Juraev Kh.O. Ways of Using Educational Materials on Alternative Energy Sources at Physics Lessons//Eastern European Scientific Journal. -Düsseldorf, 2017. № 2. - P. 83-86.

28. Kakhkharov S.K., Juraev H.O. Use of alternative energy sources at natural sciences lessons// The Way of Science. - Volgograd, 2017. № 2. - P. 148-150.

29. Kahharov S.K., Juraev Kh.O., Khamdamova N.M. Использование учебных материалов по источникам альтернативной энергии в интеграции на уроках физике // Инновации в науке. - Novosibirsk, 2019. №5 (93). -P. 17-25.

30. JuraevKh. Ways of using educational materials on alternative energy sources at natural lessons// European science review. - Austria, 2018. № 1-2. -P. 177-180.

31. Juraev Kh. Training materials on sources of the alternative energy in integration of natural sciences // Humanities and Social Sciences in Europe: Achievements and Perspectives. - Vienna, 2015. - P. 3235. 
32. Qahhorov S.Q., Samiev K.A., Jo'raev H.O. Process modeling in solar devices.Monograph. - Tashkent. ITAPRESS, 2014. - $208 \mathrm{p}$.

33. Juraev Kh.O., Khamdamova N.M. Using alternative energy sources in education // Modern humanitarian research. - Moscow, 2015. №3. - P. 42-48.

34. Каххоров С.К., Жураев Х.О., Жамилов Ю.Ю. Рециркуляционная солнечная сушильная установка // Наука и мир. - Волгоград, 2016. № 11 (39). - C. 26-28.

26. 